\title{
Reclamation Suitability Evaluation of Damaged Mined Land Based on the Limit Condition Method - Example of Pingdingshan Tianan Ten Coal Mine
}

\author{
Wu Ya-lin ${ }^{1}$, Feng You-li ${ }^{2}$, Wang Qi-sen ${ }^{3}$, Gao Chong $^{4}$, Zhang Zhuo ${ }^{5}$

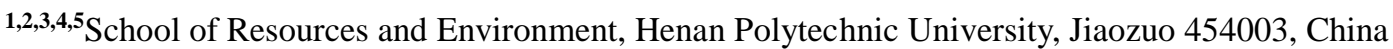

\begin{abstract}
Reclamation suitability evaluation is the basis for determining the reuse direction of damaged land. Limit condition method is the most widely used method in land reclamation suitability evaluation at present. In this paper, the limit condition method is used to evaluate the suitability of land reclamation of damaged land in Pingdingshan Tianan ten coal mine. The evaluation index of damaged area is determined as six main factors: field slope/land flatness, ponding, depth of collapse, soil texture, thickness of soil layer, irrigation and drainage conditions, and finally determine the reclamation direction of the land to be reclaimed in combination with the overall local land use planning and the overall wishes of local residents.
\end{abstract}

KEYWORDS: Reclamation suitability evaluation; Damaged mined land; Limit condition method

\section{INTRODUCTION}

With the increasingly prominent conflict between human and land in China, cherishing and rational use of land has been elevated to a national strategic level. More than $95 \%$ of primary energy, $80 \%$ of industrial raw materials and $70 \%$ of agricultural production materials in China come from mineral resources [1]. Large-scale mining of mineral resources inevitably results in the occupation and destruction of large amounts of land, which seriously restricts the sustainable development of mining areas. Land reclamation work can effectively reduce the impact on ecological environment in the process of resource extraction. Therefore, restoring land productivity, increasing effective arable land area, and reclamation of damaged land is an important initiative to realize the sustainable development of ecological environment in mining areas.

Land reclamation suitability evaluation is a prospective and predictive evaluation that determines the reasonable direction of land use to be reclaimed based on the investigation of the overall land quality and the statistics and prediction of the damaged land, and provides the basis and foundation for realizing the effective reclamation of land in mining areas ${ }^{[2-3]}$. Land reclamation suitability evaluation in mining areas lays the foundation for the planning and design of reclamation programs, the determination of reclamation directions, and the implementation of reclamation techniques, and provides a scientific basis for the rational use of land resources and the optimal allocation of land structure, and it is an important way to achieve sustainable development and ecological civilization in mining areas $\left.{ }^{[4}\right]$. In this paper, based on the analysis of the site survey and proposed damage prediction of Pingdingshan Tianan ten coal mine, the evaluation units are divided and the most suitable land reclamation direction for each evaluation unit is obtained using the limit condition method, which provides a scientific basis for the reasonable reclamation of land resources in the mine area.

\section{GENERAL SITUATION OF STUDY AREA}

The mine area spans two counties, Weidong District, Pingdingshan City and Xiangcheng County, Xuchang City, and is located in the transition area between the hills and the plains, with the overall topography being high in the north and low in the south, and the topography being moderately undulating. Surface water bodies are not developed in the mine area, which has a warm temperate continental semi-humid monsoon climate.

The total area of the mine site is $2061.58 \mathrm{hm}^{2}$, and the total area of reclamation responsibility is $1943.84 \mathrm{hm}^{2}$, including $453.16 \mathrm{hm}^{2}$ of arable land; $163.73 \mathrm{~m}^{2}$ of garden 
land; $266.27 \mathrm{hm}^{2}$ of forest land; $514.87 \mathrm{hm}^{2}$ of grassland; $51.66 \mathrm{hm}^{2}$ of transportation land; $36.40 \mathrm{hm}^{2}$ of water and water conservancy facilities; $25.74 \mathrm{hm}^{2}$ of other land $; 432.01 \mathrm{hm}^{2}$ of urban, village, industrial and mining land.

\section{RECLAMATION SUITABILITY EVALUATION}

\subsection{Evaluation scope and evaluation unit division}

(1) Scope of evaluation

The evaluation scope is the scope of reclamation responsibility, totaling $1,943.84 \mathrm{hm}^{2}$. in terms of the original land use types in the project area, it involves 8 first-class land types, including arable land, garden land, forest land, grassland, transportation land, water and water conservancy facilities land, other land, urban village and industrial and mining land. There are 17 secondary land types such as watered land, dry land, orchard, other garden land, forested land, other forested land, other grassland, highway land, rural roads, river surface, pond surface, ditch, agricultural facilities, bare land, village, mining land, scenic spots and special land. The types of damage involved are all subsidence, and the degree of damage is divided into light damage, moderate damage and heavy damage.

(2) Division of evaluation unit
The division of evaluation units should reflect the relatively homogeneous or similar nature within the unit, and comparability between units, which can objectively reflect the differences of land in a certain period and space [5]. Based on the principles of "similar land properties in the same evaluation unit" and "differences between evaluation units" [6]. The land reclamation suitability evaluation unit was divided into ten mine reclamation responsibility areas based on the type of land use, degree of damage, and the time sequence of damage of Pingdingshan Tianan ten coal mine.

The evaluation unit of land suitability was divided into 23 evaluation units within the reclamation responsibility area, based on the damage unit, and then divided into evaluation units according to the degree of damage and damage land type within the damage unit, and the basic information of each evaluation unit is shown in Table 1. Among the damaged land types, the affected towns and villages and industrial and mining land will be repaired and reinforced in time (rebuilt after individual compensation for serious damage), while transportation land and land for water and water conservancy facilities will continue to be used through maintenance and reclaimed as the original land type, and no quantitative analysis will be done.

Table 1: Division of Evaluation Units

\begin{tabular}{|c|c|c|c|}
\hline \multirow{2}{*}{ No. } & \multicolumn{2}{|l|}{ Division of evaluation unit } & \multirow{2}{*}{ Area $\left(\mathrm{hm}^{2}\right)$} \\
\hline & Damage Severity & Type of damaged land & \\
\hline 1 & \multirow{8}{*}{ Light collapse damage } & Light watered land & 5.72 \\
\hline 2 & & Light dry land & 350.14 \\
\hline 3 & & Light orchard & 86.78 \\
\hline 4 & & Light other garden & 0.45 \\
\hline 5 & & Light wooded land & 146.09 \\
\hline 6 & & Light other woodlands & 81.59 \\
\hline 7 & & Light other grasses & 342.52 \\
\hline 8 & & Light bare ground & 24.36 \\
\hline 9 & \multirow{5}{*}{ Moderate collapse damage } & Moderate dry land & 84.68 \\
\hline 10 & & Moderate orchard & 76.50 \\
\hline 11 & & Moderate wooded land & 32.01 \\
\hline 12 & & Moderate other woodland & 6.58 \\
\hline 13 & & Moderate other grasses & 172.35 \\
\hline
\end{tabular}


"Reclamation Suitability Evaluation of Damaged Mined Land Based on the Limit Condition Method-Example of Pingdingshan Tianan Ten Coal Mine"

\begin{tabular}{|c|c|c|c|}
\hline \multirow{2}{*}{ No. } & \multicolumn{2}{|l|}{ Division of evaluation unit } & \multirow{2}{*}{ Area $\left(\mathrm{hm}^{2}\right)$} \\
\hline & Damage Severity & Type of damaged land & \\
\hline 14 & & Moderate facility agricultural land & 1.38 \\
\hline 15 & Heavy collapse damage & Heavy dry and & 12.62 \\
\hline 16 & \multirow{8}{*}{$\begin{array}{l}\text { Light to moderate collapse } \\
\text { damage }\end{array}$} & Highway land & 15.44 \\
\hline 17 & & Rural Road & 36.22 \\
\hline 18 & & River surface & 13.95 \\
\hline 19 & & Pond surface & 19.97 \\
\hline 20 & & Ditch & 2.48 \\
\hline 21 & & Village & 188.46 \\
\hline 22 & & Mining land & 222.52 \\
\hline 23 & & Scenic and special land & 21.03 \\
\hline \multicolumn{3}{|c|}{ Total } & 1943.84 \\
\hline
\end{tabular}

\section{(3)Evaluation method}

The limit condition method was used to evaluate the suitability of the land reclamation. The limiting method is based on the "barrel principle" of systems engineering, which means that the final quality of a classification unit depends on the quality of the least conditioned factor ${ }^{[7]}$. According to the principle of the law of least factor, the suitability of the land and its grade are determined by the factor with the lowest suitability grade of a single factor among the selected evaluation factors ${ }^{[8]}$.

The calculation formula of the Limit Method is as follows:

$Y i=\min (Y i j)$

In the formula:

$Y i$ - final score of the $i$ th evaluation unit

$Y i j$ - score of the $i$ th evaluation unit's $j$ th eligible factor

\subsection{Selection of evaluation factors and ranking indicators}

The selection of the most important factors affecting land suitability for a particular land use or land use pattern as items to be evaluated is called evaluation factors ${ }^{[9]}$.Combining with the actual situation of Pingdingshan Tianan ten coal mine, the suitability evaluation indexes were determined as follows: field slope/land flatness, Ponding, depth of collapse, soil texture, thickness of soil layer, irrigation and drainage conditions. The main limiting factors were selected for suitability evaluation grade criteria, and other limiting factors were used as reference factors to develop the grade criteria for the main limiting factors for land reclamation suitability evaluation in the project area, as shown in Table 2.

Table 2: Evaluation Metrics System for the Lands to be Reclaimed in the Project Area

\begin{tabular}{|l|l|l|l|l|}
\hline \multicolumn{2}{|l|}{ Limiting factors and grading indicators } & $\begin{array}{l}\text { Suitable for } \\
\text { Arable land }\end{array}$ & Suitable for garden land & $\begin{array}{l}\text { Suitable for } \\
\text { forest land }\end{array}$ \\
\hline \multirow{3}{*}{ field slope / land } & -210 & 1 & 1 & 1 \\
\cline { 2 - 6 } flatness $(\circ)$ & $10 \sim 15$ & 2 & 1 & 1 \\
\cline { 2 - 6 } & & 3 & 2 & 2 \\
\hline \multirow{3}{*}{ depth of collapse $(\mathrm{m})$} & $1.5 \sim 5$ & 1 & 2 & 3 \\
\cline { 2 - 6 } & $>5$ & 2 & 1 & 2 \\
\hline
\end{tabular}


"Reclamation Suitability Evaluation of Damaged Mined Land Based on the Limit Condition Method - Example of Pingdingshan Tianan Ten Coal Mine"

\begin{tabular}{|c|c|c|c|c|}
\hline \multicolumn{2}{|c|}{ Limiting factors and grading indicators } & \multirow{2}{*}{$\begin{array}{l}\text { Suitable for } \\
\text { Arable land }\end{array}$} & \multirow{2}{*}{$\begin{array}{l}\text { Suitable for garden land } \\
1\end{array}$} & \multirow{2}{*}{ 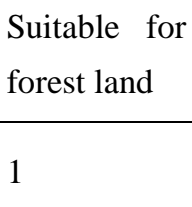 } \\
\hline \multirow{3}{*}{ soil texture } & Loamy soil、 clay loam & & & \\
\hline & Clay & 2 & 1 & 1 \\
\hline & Sandy soil & $\mathrm{N}$ & 3 & 3 \\
\hline \multirow{4}{*}{ thickness of soil layer } & $\geq 80$ & 1 & 1 & 1 \\
\hline & $60 \sim 80$ & 2 & 2 & 1 \\
\hline & $30 \sim 60$ & $\mathrm{~N}$ & 2 & 2 \\
\hline & $<30$ & $\mathrm{~N}$ & $\mathrm{~N}$ & $\mathrm{~N}$ \\
\hline \multirow{4}{*}{$\begin{array}{l}\text { irrigation and drainage } \\
\text { conditions }\end{array}$} & With guarantee & 1 & 1 & 1 \\
\hline & Unstable & 2 & 2 & 1 \\
\hline & Difficulty & 3 & 2 & 2 \\
\hline & Not available & $\mathrm{N}$ & $\mathrm{N}$ & $\mathrm{N}$ \\
\hline \multirow{3}{*}{ Ponding } & No & 1 & 1 & 1 \\
\hline & Seasonal Ponding & 2 & 2 & 2 \\
\hline & Yes & $\mathrm{N}$ & 3 or $\mathrm{N}$ & 3or $\mathrm{N}$ \\
\hline
\end{tabular}

\section{SUITABILITY EVALUATION RESULTS AND RECLAMATION DIRECTION DETERMINATION}

According to the land resource nature status of each participating unit after damage, the land quality participating item with the greatest restriction and the lowest suitability grade is used to decide the land suitability grade of the unit against the land reclamation suitability grading standard table, and the characteristics of each evaluation unit are derived. Among them, highways, rural roads, rivers, villages, etc. are maintained and reclaimed as the original land type without quantitative analysis, and the statistical results of their reclamation directions are shown in Table 3.

Table 3: Statistical table of land reclamation direction of the evaluation unit

\begin{tabular}{|c|c|c|c|}
\hline \multicolumn{2}{|c|}{ Evaluation Unit } & \multirow{2}{*}{$\begin{array}{l}\text { Area }\left(\mathrm{hm}^{2}\right) \\
15.44 \\
\end{array}$} & \multirow{2}{*}{\begin{tabular}{|l} 
Direction of Reclamation \\
highway land \\
\end{tabular}} \\
\hline 16 & highway land & & \\
\hline 17 & Rural Road & 36.22 & Rural Road \\
\hline 18 & River surface & 13.95 & River surface \\
\hline 19 & Pond surface & 19.97 & Pond surface \\
\hline 20 & Ditch & 2.48 & Ditch \\
\hline 21 & Village & 188.46 & Village \\
\hline 22 & Mining land & 222.52 & Mining land \\
\hline 23 & Scenic and special land & 21.03 & Scenic and special land \\
\hline
\end{tabular}

This evaluation is based on the principle of giving priority to arable land, and areas where the original land use type is arable land, even if they are third-class suitable agricultural land, are given priority to be reclaimed as arable land. The land whose original land use type is forest land and grassland has a low agricultural evaluation score even if it is third-class suitable for agriculture, so according to the requirements of the overall land use plan and combined with 1020 the results of the adaptability evaluation, its original use type is kept unchanged. Based on the results of the suitability evaluation of the evaluation units, comprehensive land reclamation suitability evaluation and social, economic, safety and public opinion factors, and from the analysis of the restrictive factors of each evaluation unit site, the final direction of reclamation for each evaluation unit of the mine was determined, as detailed in Table 4.

Wu Ya-lin', ETJ Volume 6 Issue 09 September 2021 
"Reclamation Suitability Evaluation of Damaged Mined Land Based on the Limit Condition Method-Example of Pingdingshan Tianan Ten Coal Mine"

Table 4: Statistical table of the evaluation level and reclamation direction of land reclamation suitability of the evaluation unit

\begin{tabular}{|c|c|c|c|c|c|c|c|c|c|c|c|c|c|c|}
\hline \multirow{3}{*}{\multicolumn{2}{|c|}{$\begin{array}{l}\text { Evaluation } \\
\text { Unit }\end{array}$}} & \multicolumn{6}{|c|}{ Evaluation factors } & \multicolumn{6}{|c|}{ Suitability evaluation results } & \multirow{3}{*}{$\begin{array}{l}\text { Direction } \\
\text { of } \\
\text { reclamati } \\
\text { on }\end{array}$} \\
\hline & & \multirow{2}{*}{$\begin{array}{l}\text { field } \\
\text { slope } \\
\text { /land } \\
\text { flatnes } \\
\text { s/ }\end{array}$} & \multirow{2}{*}{$\begin{array}{l}\text { Depth } \\
\text { of } \\
\text { collap } \\
\text { se/m }\end{array}$} & \multirow[b]{2}{*}{$\begin{array}{l}\text { soil } \\
\text { texture }\end{array}$} & \multirow{2}{*}{$\begin{array}{l}\text { thicknes } \\
\text { s of soil } \\
\text { layer/c } \\
\text { m }\end{array}$} & \multirow{2}{*}{$\begin{array}{l}\text { irrigation } \\
\text { and } \\
\text { drainage } \\
\text { conditions }\end{array}$} & \multirow{2}{*}{ Pondi } & \multicolumn{2}{|c|}{$\begin{array}{l}\text { Suitable for Arable } \\
\text { land }\end{array}$} & \multicolumn{2}{|c|}{$\begin{array}{l}\text { Suitable for } \\
\text { garden land }\end{array}$} & \multicolumn{2}{|c|}{$\begin{array}{l}\text { Suitable for } \\
\text { forest land }\end{array}$} & \\
\hline & & & & & & & & Grad & $\begin{array}{l}\text { Main } \\
\text { limitations }\end{array}$ & Grad & $\begin{array}{l}\text { Main } \\
\text { limitatio } \\
\text { ns }\end{array}$ & erad & $\begin{array}{l}\text { Main } \\
\text { limitatio } \\
\text { ns }\end{array}$ & \\
\hline 1 & $\begin{array}{l}\text { Light } \\
\text { watered } \\
\text { land }\end{array}$ & $<3$ & $<1.5$ & $\begin{array}{l}\text { Loamy } \\
\text { soil }\end{array}$ & $>80$ & $\begin{array}{l}\text { With } \\
\text { guarantee }\end{array}$ & No & 1 & & 1 & & 1 & & $\begin{array}{l}\text { watered } \\
\text { land }\end{array}$ \\
\hline 2 & $\begin{array}{l}\text { Light dry } \\
\text { land }\end{array}$ & $<3$ & $<2$ & $\begin{array}{l}\text { Loamy } \\
\text { soil }\end{array}$ & $>80$ & $\begin{array}{l}\text { With } \\
\text { guarantee }\end{array}$ & No & 1 & & 1 & & 1 & & dry land \\
\hline 3 & $\begin{array}{l}\text { Light } \\
\text { orchard }\end{array}$ & $<3$ & $<2$ & $\begin{array}{l}\text { Loamy } \\
\text { soil }\end{array}$ & $>80$ & $\begin{array}{l}\text { With } \\
\text { guarantee }\end{array}$ & No & 1 & & 1 & & 1 & & orchard \\
\hline 4 & $\begin{array}{l}\text { Light } \\
\text { other } \\
\text { garden }\end{array}$ & $<3$ & $<2$ & $\begin{array}{l}\text { Loamy } \\
\text { soil }\end{array}$ & $>80$ & $\begin{array}{l}\text { With } \\
\text { guarantee }\end{array}$ & No & 1 & & 1 & & 1 & & $\begin{array}{l}\text { other } \\
\text { garden } \\
\text { land }\end{array}$ \\
\hline 5 & $\begin{array}{l}\text { Light } \\
\text { wooded } \\
\text { land }\end{array}$ & $6 \sim 15$ & $<2$ & $\begin{array}{l}\text { Loamy } \\
\text { soil } \\
\text { Sandy } \\
\text { soil }\end{array}$ & $>80$ & Unstable & No & 3 & $\begin{array}{l}\text { field slope } \\
\text { land flatness, } \\
\text { soil texture }\end{array}$ & 2 & $\begin{array}{l}\text { field } \\
\text { slope } \\
\text { land } \\
\text { flatness }\end{array}$ & 2 & $\begin{array}{l}\text { field } \\
\text { slope } \\
\text { land } \\
\text { flatness }\end{array}$ & forested \\
\hline 6 & \begin{tabular}{|l|} 
Light \\
other \\
woodland \\
s
\end{tabular} & $6 \sim 15$ & $<2$ & $\begin{array}{l}\text { Loamy } \\
\text { soil } \\
\text { Sandy } \\
\text { soil }\end{array}$ & $>80$ & Unstable & No & 3 & $\begin{array}{l}\text { field slope } \\
\text { land flatness, } \\
\text { soil texture }\end{array}$ & 2 & $\begin{array}{l}\text { field } \\
\text { slope } \\
\text { land } \\
\text { flatness }\end{array}$ & 2 & $\begin{array}{l}\text { field } \\
\text { slope } \\
\text { land } \\
\text { flatness }\end{array}$ & $\begin{array}{l}\text { other } \\
\text { forested } \\
\text { land }\end{array}$ \\
\hline 7 & $\begin{array}{l}\text { Light } \\
\text { other } \\
\text { grasses }\end{array}$ & $6 \sim 15$ & $<2$ & $\begin{array}{l}\text { Loamy } \\
\text { soil } \\
\text { Sandy } \\
\text { soil }\end{array}$ & $30 \sim 60$ & Unstable & No & 3 & $\begin{array}{l}\text { field slope } \\
\text { land flatness, } \\
\text { soil texture }\end{array}$ & 2 & $\begin{array}{l}\text { field } \\
\text { slope } \\
\text { land } \\
\text { flatness }\end{array}$ & 2 & $\begin{array}{l}\text { field } \\
\text { slope } \\
\text { land } \\
\text { flatness }\end{array}$ & $\begin{array}{l}\text { other } \\
\text { grassland }\end{array}$ \\
\hline 8 & $\begin{array}{l}\text { Light bare } \\
\text { ground }\end{array}$ & $6 \sim 15$ & $<2$ & $\begin{array}{l}\text { Sandy } \\
\text { soil }\end{array}$ & $<30$ & Unstable & No & 3 & $\begin{array}{l}\text { field slope } \\
\text { land flatness, } \\
\text { soil texture }\end{array}$ & 3 & soil & 3 & $\begin{array}{l}\text { soil } \\
\text { texture }\end{array}$ & $\begin{array}{l}\text { other } \\
\text { grassland }\end{array}$ \\
\hline
\end{tabular}


Continue Table 4:

\begin{tabular}{|c|c|c|c|c|c|c|c|c|c|c|c|c|c|}
\hline \multirow{3}{*}{$\begin{array}{l}\text { Evaluation } \\
\text { Unit }\end{array}$} & \multicolumn{6}{|c|}{ Evaluation factors } & \multicolumn{6}{|c|}{ Suitability evaluation results } & \multirow{3}{*}{$\begin{array}{l}\text { Direction } \\
\text { of } \\
\text { reclamati } \\
\text { on }\end{array}$} \\
\hline & \multirow{2}{*}{\begin{tabular}{|l} 
field \\
slope \\
/land \\
flatnes \\
s/
\end{tabular}} & \multirow{2}{*}{$\begin{array}{l}\text { Depth } \\
\text { of } \\
\text { collap } \\
\text { se/m }\end{array}$} & \multirow[b]{2}{*}{ 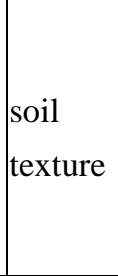 } & \multirow{2}{*}{$\begin{array}{l}\text { thicknes } \\
\text { s of soil } \\
\text { layer/c } \\
\text { m }\end{array}$} & \multirow{2}{*}{$\begin{array}{l}\text { irrigation } \\
\text { and } \\
\text { drainage } \\
\text { conditions }\end{array}$} & \multirow[b]{2}{*}{$\begin{array}{l}\text { Pondi } \\
\text { ng }\end{array}$} & \multicolumn{2}{|c|}{$\begin{array}{l}\text { Suitable for Arable } \\
\text { land }\end{array}$} & \multicolumn{2}{|c|}{$\begin{array}{l}\text { Suitable for } \\
\text { garden land }\end{array}$} & \multicolumn{2}{|c|}{$\begin{array}{l}\text { Suitable for } \\
\text { forest land }\end{array}$} & \\
\hline & & & & & & & erad & $\begin{array}{l}\text { Main } \\
\text { limitations }\end{array}$ & Grad & $\begin{array}{l}\text { Main } \\
\text { limitatio } \\
\text { ns }\end{array}$ & \begin{tabular}{|l|l}
$\operatorname{Grad}$ & 1 \\
$\mathrm{e}$ & 1 \\
\end{tabular} & $\begin{array}{l}\text { Main } \\
\text { limitatio } \\
\text { ns }\end{array}$ & \\
\hline $9 \begin{array}{l}\text { Moderate } \\
\text { dry land }\end{array}$ & $<3$ & $2 \sim 5$ & $\begin{array}{l}\text { Loamy } \\
\text { soil }\end{array}$ & $>80$ & $\begin{array}{l}\text { With } \\
\text { guarantee }\end{array}$ & \begin{tabular}{|l} 
Seaso \\
nal \\
Pondi \\
ng \\
\end{tabular} & 2 & $\begin{array}{l}\text { depth of } \\
\text { collapse } \\
\text { Ponding }\end{array}$ & 2 & $\begin{array}{l}\text { depth of } \\
\text { collapse }\end{array}$ & 2 & $\begin{array}{l}\text { depth of } \\
\text { collapse }\end{array}$ & dry land \\
\hline $10 \begin{array}{l}\text { Moderate } \\
\text { orchard }\end{array}$ & $\mid<3$ & $2 \sim 5$ & $\begin{array}{l}\text { Loamy } \\
\text { soil }\end{array}$ & $>80$ & $\begin{array}{l}\text { With } \\
\text { guarantee }\end{array}$ & No & 2 & $\mid \begin{array}{ll}\text { depth } & \text { of } \\
\text { collapse }\end{array}$ & 2 & $\left|\begin{array}{ll}\text { depth } & \text { of } \\
\text { collapse }\end{array}\right|$ & 2 & $\begin{array}{l}\text { depth of } \\
\text { collapse }\end{array}$ & orchard \\
\hline $11\left|\begin{array}{l}\text { Moderate } \\
\text { wooded } \\
\text { land }\end{array}\right|$ & $6 \sim 15$ & $2 \sim 5$ & $\begin{array}{l}\text { Loamy } \\
\text { soil } \\
\text { Sandy } \\
\text { soil }\end{array}$ & $>80$ & $\begin{array}{l}\text { With } \\
\text { guarantee }\end{array}$ & No & 3 & $\mid \begin{array}{l}\text { field slope } \\
\text { land flatness } \\
\text { soil texture }\end{array}$ & 2 & $\begin{array}{l}\text { depth of } \\
\text { collapse }\end{array} \mid$ & 2 & \begin{tabular}{|l|l} 
soil & $\mathrm{f}$ \\
texture & 1
\end{tabular} & $\begin{array}{l}\text { forested } \\
\text { land }\end{array}$ \\
\hline $12 \mid \begin{array}{l}\text { Moderate } \\
\text { other } \\
\text { woodland }\end{array}$ & $6 \sim 15$ & $2 \sim 5$ & $\begin{array}{l}\text { Loamy } \\
\text { soil } \\
\text { Sandy } \\
\text { soil }\end{array}$ & $>80$ & Unstable & No & 3 & $\mid \begin{array}{l}\text { field slope } \\
\text { land flatness } \\
\text { soil texture }\end{array}$ & 3 & $\begin{array}{l}\text { soil } \\
\text { texture }\end{array}$ & 3 & \begin{tabular}{l|l} 
soil & $\mathrm{f}$ \\
texture & $\mathrm{f}$
\end{tabular} & $\begin{array}{l}\text { other } \\
\text { forested } \\
\text { land }\end{array}$ \\
\hline $13\left|\begin{array}{l}\text { Moderate } \\
\text { other } \\
\text { grasses }\end{array}\right|$ & $6 \sim 15$ & $2 \sim 5$ & $\begin{array}{l}\text { Loamy } \\
\text { soil } \\
\text { Sandy } \\
\text { soil }\end{array}$ & $30 \sim 60$ & Unstable & No & 3 & $\left|\begin{array}{l}\text { field slope } \\
\text { land flatness } \\
\text { soil texture }\end{array}\right|$ & 3 & $\begin{array}{l}\text { soil } \\
\text { texture }\end{array}$ & 3 & $\mid \begin{array}{l}\text { soil } \\
\text { texture }\end{array}$ & $\begin{array}{l}\text { other } \\
\text { grassland }\end{array}$ \\
\hline $14 \mid \begin{array}{l}\text { Moderate } \\
\text { facility } \\
\text { agricultur } \\
\text { al land }\end{array}$ & $<3$ & $2 \sim 5$ & $\begin{array}{l}\text { Sandy } \\
\text { soil }\end{array}$ & $30 \sim 60$ & Unstable & No & $\mathrm{N}$ & soil texture & 3 & $\begin{array}{l}\text { soil } \\
\text { texture }\end{array}$ & 3 & soil & $\begin{array}{l}\text { facility } \\
\text { agricultur } \\
\text { al land }\end{array}$ \\
\hline $15 \mid \begin{array}{l}\text { Heavy dry } \\
\text { and }\end{array}$ & $<3$ & $>5$ & $\begin{array}{l}\text { Loamy } \\
\text { soil }\end{array}$ & $>80$ & $\begin{array}{l}\text { With } \\
\text { guarantee }\end{array}$ & No & 3 & $\begin{array}{l}\text { depth } \\
\text { collapse }\end{array}$ & 3 & $\left|\begin{array}{cc}\text { depth } & \text { of } \\
\text { collapse }\end{array}\right|$ & 3 & $\begin{array}{l}\text { depth of } \\
\text { collapse }\end{array} \mid$ & dry land \\
\hline
\end{tabular}

\section{CONCLUSION}

Taking Pingdingshan Tianan ten coal mine as an example in this paper, the suitability of land reclamation is analyzed and evaluated using the two-level classification system of land suitability class and land quality, and the limit condition method, and the reclamation plan is determined for the land destroyed by mining, It can provide basis for rational utilization of damaged land, improvement of ecological environment, improvement of reclamation technology, protection of cultivated land, delimitation of basic farmland and land regulation planning.

\section{REFERENCES}

1. Qian Lv. Discussion on the impact of mining on ecological environment and ecological restoration of mining areas[A]. Proceedings of the 2015 Annual Academic Conference of the Chinese Society of Environmental Science [C].2015.

2. Li Xia, Zhou Zi Qiang. Characteristics and Prospects of Land Reclamation Suitability Evaluation Methods[J].Gansu Science and 
Technology, 2014,30(04):36-39.

3. Wang Duan. Land reclamation suitability evaluation study [D]Kunming University of Science and Technology.2016.

4. Du Kaiyuan,Hu Haifeng,Kang Lixun. Application of Suitability Evaluation in Land Reclamation Technology in Mining Areas][J].Journal of Shanxi Agricultural Sciences,2010,38(02):46-48+52.

5. Yang Hui. Land suitability evaluation based on the limit condition method-A mining area as an example][J].,Journal of Green Science and Technology2019(16):269-270.

6. Wu Songfeng,Li Qi,Wang Dawei,Pan Junjie. Evaluation of suitability of land reclamation for small mines based on limit condition method[A]Henan Earth Science Bulletin Volume
2016.[C].2016.

7. Li Nan,Han Kunlin. Analysis of suitability evaluation of land reclamation-Example of Yongfa coal mine in Heihe City[J].Chinese \& Foreign Entrepreneurs, 2018(01):8.

8. Zhu Wenli. Evaluation of the suitability of land reclamation in the second well of Xicha coal mine in Fenyi, Jiangxi Province[D].Shandong University of Science and Technology,2014.

9. Liang Yeping,Bi Rutian. Land suitability evaluation of mining areas based on the exponential sum method and limiting conditions method-a case study of Mengjiayao coal mine][J].Journal of Shanxi Agricultural University(Natural Science Edition),2014,34(05):436-441. 